\title{
Family Communication Model in Forming Pious Children
}

\author{
Yan Hendra ${ }^{1}$, Ribut Priadi ${ }^{1}$ \\ ${ }^{1}$ Lecturer in University of Muhammadiyah Sumatera Utara (UMSU) Medan Indonesia
}

\begin{abstract}
Piousness children can not be separated from the communication built by parents in the family. Through this research a search for family communication was carried out so as to form a pious child. The research problem is, what is the model of family communication in sholeh children. The study uses a qualitative approach with qualitative descriptive methods. Research data is obtained through interviewing parents of pious children. The results showes that the family communication model in forming pious children was built by four foundations, namely the intensity of family communication consisting of frequency and duration of communication, family communication patterns consisting of atmosphere, communication and flow of communication, communication methods that tended to be persuasive and coercive, methods planting of value values consisting of exemplary methods, habituation, discipline, enforcement of rules that must be obeyed by children.
\end{abstract}

Keywords : family communication; pious (sholeh) child

\section{Introduction}

Children are a community group that determines the future of the nation. The strategics position occupied by children makes them an important community group, this is because children are the younger generation who will take control of the life of the community, nation and state in the future. The age of young and innocent children will make it easier for parents to shape children's attitudes and behavior in accordance with what their parents want.

Children are the mandate of God given to parents. For this mandate, Allah obliges every parent to care for, nurture and educate children to become good, smart, noble children and to avoid things that are not good, as the word of Allah SWT in the letter At Tahrim / 66: 6 , "Hi those who believe keep yourselves and your family from the torment of hell fire." As long as in parenting, parents are required to provide knowledge, skills, religious values and moral values that exist in people's lives.

Every parent certainly wants their child to be a good, smart and noble child or who is more often called a pious child. A pious child is the dream of every parent. Parents will be happy and happy about their pious children. Not only parents, peers and society will also be happy with pious children. Allah Almighty gave privileges to children who were blessed by receiving prayers from pious children who expected Allah's forgiveness from the sins of their parents.

The success of a child can be seen in his life. The pious child obeys the advice of kindness from both parents, from his brother and sister, his teacher and the advice of parents of members of the community where he is located. Children who are pious obey carry out religious orders, such as praying five times, fasting or other obligatory worship. The achievement of a child will also be seen from his good and polite attitude and attitude, polite speech both at home, at school and in the community.

A pious child is not formed just like that, but surely there are environmental factors that shape it, one of which is family communication. Research related to family communication generally sees the effect of family communication on children's attitudes and behavior. Attitudes and behaviors that are generally seen are positive attitudes and behaviors. 
The study entitled "The Influence of Family Communication, Islamic Education Teachers and Peers on Islamic Communication Ethics of Junior High School Students in Medan City. Proved that family communication has a positive influence on Islamic communication ethics of children /students as seen from good attitudes and behavior / sholeh. The better the quality of family communication carried out by parents to their children, the better the communication ethics of Islamic children (Hendra, 2016: 184).

The effect of family communication on children is also evidenced by a study entitled "The Influence of Family Communication on Student Creativity in Bekasi State Middle School 19 West Java Province. The results of the study show that the family environment is very potential to develop children's / student creativity in learning. Through full moral and material support from parents in meeting the learning needs of children / students can support children's learning motivation. Attention and involvement of parents in learning problems can make it easier for children to overcome their problems. (Aprina Sari, 2011).

The contents of the message and the way the message is delivered will determine the effectiveness of family communication. The study entitled "Effective Communication in Western and Islamic Perspectives" concluded that in the Islamic perspective, the content of messages and ways of delivering effective messages in family communication must be based on the principles / ethics of Islamic communication contained in the Koran, namely: Qawlan Ma'rufan (good words), Qawlan Sadidan (right words), Qawlan Balighan (words with soul), Qawlan Kariman (noble words), Qawlan Maisuran (proper words), Qaulan Layyinan (meek words). (Hendra, 2017: 209).

Research on the content of the message and the way in which the message is conveyed based on the principles / ethics of Islamic communication has been carried out through research entitled "Thematic Interpretation of Verbal Communication in the Koran (Qaulan Balighan (an-Nisa: 63), Layered Qaulan (Thaha: 44)" Based on the study, it was concluded that the qaulan balighan (touching words of the soul) and the final qaulan (gentle speech) would be effective if carried out by communicators who have high credibility.The parents' credibility in family communication would determine the effectiveness of the principles / ethics of Islamic communication in family communication. (Hendra, 2017: 164-171).

The effect of family communication on children is also evidenced by a study entitled "The Role of Family Communication in Preventing Juvenile Delinquency in Malalayang Village I, Malalayang District, Manado".

The results of the study showed that through good family communication the teenagers would be good and always be able to protect themselves from bad behavior ... (JPM Tangkudung, 2014).

Based on the previous study it can be concluded that family communication has the power to shape children's attitudes and behavior. The effectiveness of family communication in addition to being determined by the credibility of parents as communicators, is also determined by the content of the message and the way the message is delivered, which is based on the principles / ethics of Islamic communication. Based on this, the researchers believe that through this research a family communication model can be produced in forming pious children. 


\section{Review of Literature}

\subsection{Family Communication}

In simple terms it can be said that family communication is communication between fellow family members consisting of father, mother and. In this family communication, the father or mother generally occupy a position as communicators, and the child occupies the position of communicant. Family communication generally occurs in homes interpersonally between parents and children. In addition to occurring directly, family communication can also occur indirectly, namely through communication media such as cellphones and other media.

Family life is bound by the existence of relationships between family members. Relationships in the family can be viewed from the dimensions of blood relations and social relations. The family in the dimension of blood relations is a unit that is bound by the relationship or blood relations between one another. While in the dimensions of social relations, the family is a unit that is bound by the existence of interconnected or interacting and influencing each other with each other even though among them do not have blood relations. (Djamarah, 2004: 16)

Communication between parents and children is an important necessity in order to nurture and educate children, especially children aged between 6-12 years. Through family communication between parents and children form a relationship between parents and children. With regard to this, Galvin (2004: 52) suggests that family communication is as a symbiosis, the transactional process creates and divides meaning in the family.

Communication intensity that occurs every day between parents and children, especially children between the ages of 6-12 years will form a pattern of family communication. The formation of this communication pattern is inseparable from the orientation of the attitude and communication behavior of parents along with the values and rules that apply in the family. The pattern of family communication can be seen from the four types of family communication patterns as follows:

a. Pattern of consensual family communication. This communication pattern is characterized by a high orientation to conversation and conformity. Their communication is characterized by emphasizing openness and exploring new ideas, as well as the desire to preserve the hierarchy in the family.

b. Pattern of pluralistic family communication. This communication pattern is characterized by a high orientation to conversation, but the orientation towards their conformity is low. They are more likely to be involved in openness, and unlimited discussion among all family members on various topics.

c. Protective family communication pattern. This communication pattern is characterized by a low, but high level of conversation orientation in conformity orientation. Their communication tends to emphasize the authority of parents and parents' beliefs that they must determine all kinds of decisions for their children.

d. Free family communication pattern (laisess-faire). This communication pattern is characterized by families with conversation orientation and low conformity orientation. They have relatively little interaction between family members. Parents show relatively little interest in their children's decisions. Nor does it reveal the value communication that parents make to children. (Stewart, 2013: 279). 
Every family has a certain family communication pattern. This pattern of communication is sometimes formed intentionally or also formed accidentally. The pattern of communication that is formed intentionally means that parents intentionally plan to create a family communication pattern for a particular purpose. Communication that takes place in the family generally has goals that are more directed towards the educational aspect. Through family communication there are a number of norms that parents want to instill to their children. Such norms, for example, religious norms, moral norms, social norms, ethical norms, aesthetic norms, and moral norms. (Djamarah, 2012: 37).

In family communication, parents (father / mother) can play their role in nurturing and educating their children. Parke and Buriel (1998) say that one way to conceptualize the role of parents in child development is to place parents as managers of children's lives, especially when children are young. In the process of family communication, mothers are more likely to take care roles than fathers. (Santrock, 2007: 164).

\subsection{Pious Child}

Islamic teachings place parents as the main constituents of children's attitudes and behavior. It is parents who are responsible for forming children's attitudes and behavior. Rasulullah Shallallahu'alaih wasallam said:

"Every child is born according to his nature, it is his parents who make him Jewish, Christian, and / or religious. (Khon, 2014: 241)

The word of the Prophet emphasized the importance of the role of parents in nurturing and educating in order to form pious children.

A pious child is a dream for every parent. To get a good child is determined by how parents educate their children. Forming children into pious children is not an easy job. Parents who are serious in caring for and educating their children will be able to successfully shape their children into pious children, whereas parents who are negligent and less concerned with their children make it difficult for them to shape their children into pious children.

Forming pious children is inseparable from the efforts of parents to shape the child's personality. The process of forming a child's personality is mainly carried out by parents in the family (Yusmiar, 2015: 76). So that the process of forming a child's personality can be carried out well then every parent must know and be able to apply several methods / approaches or approaches in shaping the child's personality so that he can become a pious child.

Related to the method of forming a child's personality, Nawawi (1993: 213-238) suggests this with the term approach. According to him there are several approaches that can be done in shaping children's personality. the approach is:

a. Approach to the exemplary method

The exemplary method approach departs from the assumption that the learning process is very much done by imitating children against various parental behaviors, including communication behavior observed by children. Children's language mainly adopts parental language.

b. Approach to the habit method

In addition to giving exemplary, children's personality can be formed by parents through certain habits that parents apply to children. When parents get children to do 
something, at that time parents are instilling various values in their children. Sdeiring with the passage of time the habit becomes a child's behavior that is difficult to change.

c. Approach to advice and story methods

Giving good advice and telling children about good things is a communication activity that can be done by their parents. The method of advice and stories really requires the ability of parents to communicate with their children. Through communication, parents can give advice and tell stories about goodness.

d. The disciplinary method approach

The application of discipline to children will give awareness to children of the rights and obligations and responsibilities of children. Instilling discipline in children will give strength to children to be able to carry out their development tasks properly.

e. Approach to participation methods

Humans as social creatures need the presence of others, as well as children. Wise parents will be able to determine which activities the child needs to be accompanied. Conversely, parents should also include children in certain activities and provide roles that suit them. Through this participation, children will learn to be creative and participatory people.

If you pay close attention to the five methods of approach forming the personality of a child, it can be said that the success of its application is largely determined by communication factors, meaning that each approach cannot be applied without the communication of parents and children in the family. Through effective communication, each method approach in shaping a child's personality can take place so that children can be formed into pious children.

Children can be known from the nature / character and behavior that they show in their daily lives, both at home, school and in the community. Children can be marked by several characteristics / behavior and behavior as follows:

a. Faithful and devoted to Allah SWT. Sholeh children believe and devote to Allah SWT. Faith and devotion perfectly.

b. Love God and His Messenger. The pious child loves Allah by not supporting him and loving the apostle by following his sunnah

c. Maintain prayer and worship. The pious child sets up his prayer on time and is full of specialties and reads the Koran and practices it.

d. Devote to both parents. Sholeh children glorify their parents by doing good, polite and full of manners when communicating with their parents.

e. Love of science. Good children always diligently study and have a strong desire to increase their knowledge.

f. Endowed kharimah. Sholeh children have noble character, have the character and behavior that is commendable, honest, kind, humble, forgiving, polite and polite when speaking. 


\section{Research Methodology}

\subsection{Methodology}

This research was conducted using a qualitative approach with in-depth interview methods (Dept Interviews). (Kriyantono, 2012: 63). The researcher conducted a face-to-face interview in depth to gather information from the speakers. To get as much data as possible, researchers also conducted nonparticipant observations at the study site.

\subsection{Interviewees}

Research resource persons are parents (father / mother) of junior high school students in the city of Medan. To get speakers, it is done by asking for help from teachers who know their students who are in the category of pious children. After obtaining these criteria, the researchers also checked the parents of the students to determine whether their children were in the category of pious children.

The category of pious children refers to the characteristics of pious children that have been described in the literature review. The number of informants is determined based on the data saturation limit, meaning that if the data that has been obtained from several sources shows a high level of similarity, the researcher decides the data has been saturated and no longer needs to increase the number of speakers.

To test the validity of the data obtained from the speaker (father / mother) data triangulation was carried out by confirming to the child about the answers of the informant (father / mother) to the questions raised by the researcher. The collected data is then analyzed by categorizing it based on the characteristics of the communication elements found in the process of family communication between parents and children. It is then tried to arrange it into a basic material to build a draft communication model.

The output produced is a draft family communication model design which will then be used as a study in making a family communication model to form pious children. This output will then be used as a module that can become a family communication forum for Muslim families to form pious children.

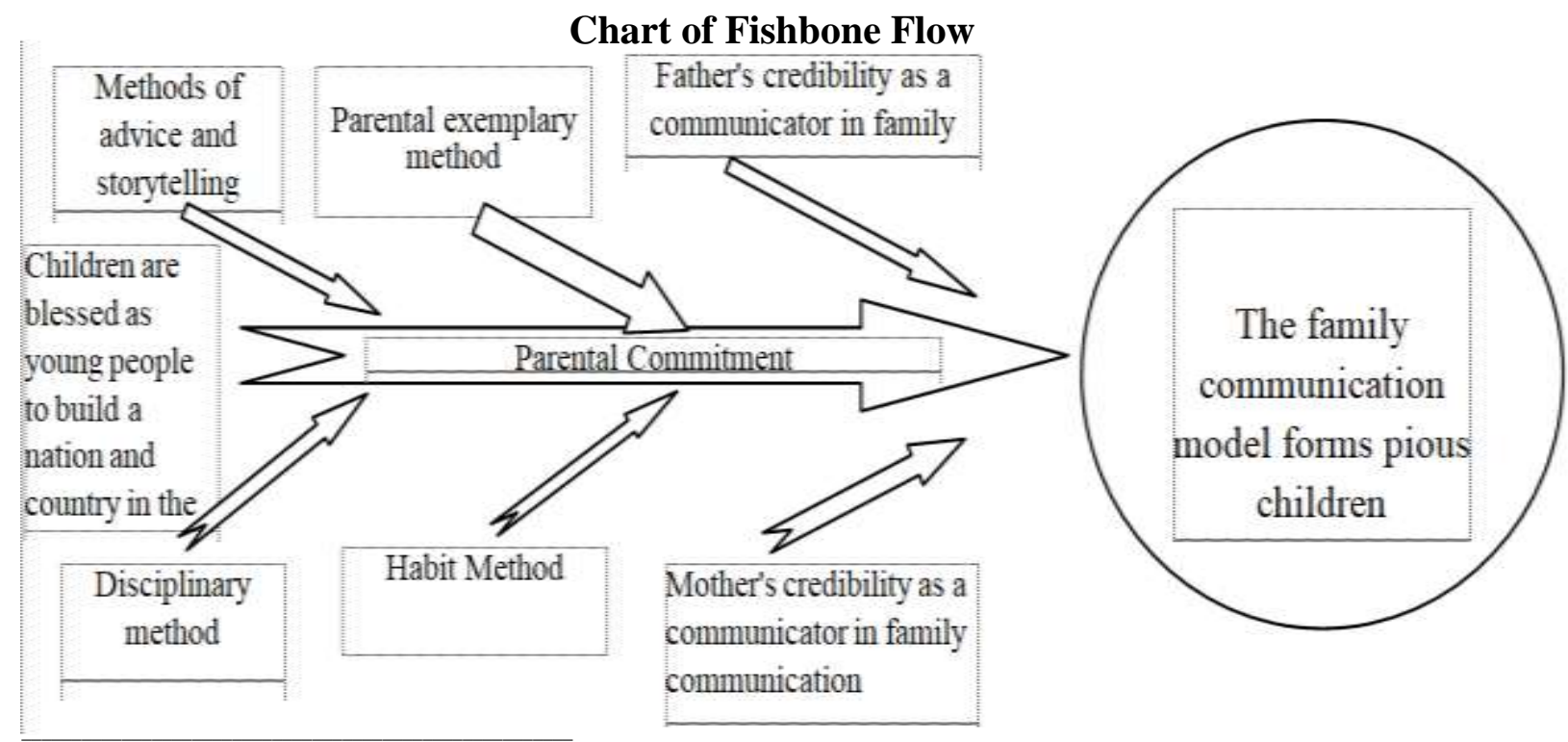

DOI : https://doi.org/10.33258/birci.v2i1.145 
This research was applied research. Applied research was carried out to produce a product, one of which was in the form of a model, this applied research is carried out to produce output in the form of a family communication model to form pious children. The communication model as a product of this study could be used by parents in Islamic families to form pious children.

\section{Discussion}

Family communication between parents and children occupies an important position in shaping the child's personality. Through family communication, parents do care for their children. Effective family communication means that the communication is going well, smooth and has a positive effect on the child. The positive effect of communication can be seen from the attitudes and behavior of children in everyday life. Conversely, ineffective family communication means that the communication does not have a positive effect on the child, it can even be a negative effect on the child. The effect of negative communication can be seen from the attitudes and behavior of children in everyday life.

Children's attitudes and behavior can be used as an indicator in assessing the effectiveness of family communication. The attitude and behavior of a good child is a characteristic of pious children. The formation of pious children is inseparable from the role of family communication. Analysis of family communication in the families of pious children will be able to explain the processes, patterns and mechanisms of family communication. Through systematic analysis, a family communication model can be created in forming pious children. This study aims to produce a model of family communication in sholeh children.

Research data obtained through interviews with parents about family communication in the family of children should be expressed in several categories, namely:

a. The intensity of family communication

b. Pattern of family communication

c. Communication techniques

d. Planting methods of value values

The following is presented research data on family communication obtained from interviewees through interviews.

Based on the data obtained through interviews with the five informants, information related to the intensity of parental and child communication in instilling morality and religious values is as follows:

\subsection{The intensity of Family Communication}

In general, the five speakers answered that the intensity of their communication with children in instilling morality and religious values is relative, meaning that the intensity depends on the availability of time. If the time is free, the intensity of communication in terms of frequency of communication and the duration of communication is higher when compared to communication at a narrow time. With the free time with children, they are more flexible and more relaxed in instilling morality and religious values with children. 
Parties who are more intense in communicating with children in instilling morals a religion.

Based on data obtained through interviews with the five speakers, related to parties who are more intensely communicating in instilling morality and religious values to children, information is obtained that mothers are more intense in communicating with children than fathers. This is because mothers have more availability when meeting and together with their children, while fathers spend less time because they are more busy working, but one of the speakers also answered that this intensity is relative, meaning between them (father and mother) there is nothing more dominate in terms of intensity of communicating with children. The communication intensity of children with their father and mother is not much different.

\subsection{There are Several Ways and Patterns of Communication.}

The atmosphere when communicating to instill morality and religious values to children.

Based on the data obtained from the five sources, information was obtained that their communication with children was mostly done at night when they and their children were at home, both at dinner together and after dinner. Nighttime is an important time for the family. The night creates a comfortable and calm atmosphere so that it is good to use to chat, chat with children. On that occasion they used to chat, talk with children. In this atmosphere, besides controlling their learning activities and children's play activities, they are also used to instill morality and religious values to children.

\subsection{The Form of Communication in Instilling Morals and Religious Values for Children.}

Based on the data obtained from the five sources, information was obtained that the form of communication they use in instilling morality and religious values to children is through direct face-to-face communication. If direct communication cannot be carried out, they communicate with children through mobile phones, but this is only done by resource persons who indeed give permission to their children to use mobile phones. For informants who do not allow their children to use mobile phones, communication messages from them can also be conveyed through intermediaries, namely their husbands or wives who then forward the message to their children.

Communication flows that occur when instilling morals and religious values to children.

The five speakers said that the communication that occurred when they instilled morality and religious values to their children was reciprocal. This means that the communication that occurs takes place reciprocally between parents and their children. They give children the opportunity to respond in the form of explanations, self-defense when parents find out about the things they ask their children. The same goes for proposals, suggestions and requests from children to parents, in this case the resource person explained that they gave freedom to children to submit a request or permission to their parents. In relation to asking for something from parents, children generally convey to their mothers in advance to get support from their mothers so that their mother's permission for the child's permission can be strengthened.

\subsection{Method of Cultivating Piousness Values:}

Teach Moral and Religious Values to Children 
Based on the results of interviews with five informants, namely parents of sholeh children, information was obtained that they all had instilled morality and religious values to children. This value planting is generally done when the child is three, four years old and there is also when the child enters kindergarten school. There are also those who say that the cultivation of morality and religious values they do when children are babies. Planting morality and religious values is generally done by reminding children to do certain behaviors, such as reminding children to accept something with their right hand and thanking the giving. In addition, it is done by giving examples of example to children. For example, older people exemplify polite behavior when speaking. Whereas instilling religious values is exemplified by parents by performing religious services, such as praying and fasting. The service is directly seen by the child. Through this example the child will imitate the religious worship exemplified by parents to him and the child will not protest if told to pray or fast. Instilling religious values with children is also done by inviting children to prayer in congregation at home and sometimes being invited to a holat to the mosque.

- Make rules that must be obeyed by the child in forming pious children.

Based on the data obtained through interviews with the five speakers, information was obtained as follows.

The five speakers said that they had made rules that must be obeyed by children. The rules include the obligation to pray and encourage children to read the Koran. In addition, rules are also applied in terms of rules regarding the distribution of child duties at home, rules about time to play and time to study at home. Rules about using Android. They forbid their children from using Android excessively, some even forbid their children to use andoid.

- Consistent with rules that have been made to regulate children's behavior.

Based on data from the sources, information was obtained that the five speakers remained consistent with the enforcement of the rules they had made. Every time they keep reminding their children to carry out existing rules. If the child violates these rules, the child is given sanctions in the form of reprimand or punishment.

- Efforts are made so that children diligently carry out prayer services. I continue to make efforts so that children remain diligent in performing prayers. His name must have been a time when he began to neglect to perform prayers, therefore I constantly reminded the children not to leave the prayer once in a while. In order not to leave the prayer, I instilled discipline in the child, especially the time discipline in performing prayers. As soon as I enter prayer time, I remind the children to immediately pray. Because they are accustomed to praying, when they enter prayer time, the children immediately pray. Besides that, I also familiarize children with prayer in congregation. To familiarize this congregational prayer, I often invite children to Maghrib prayers in congregation both at home and in the mosque near the house.

\subsection{Communication Techniques as Follows:}

- The technique of communicating with children when instilling achievement values.

Based on the answers given by the speakers, it can be stated that in general the five speakers explained that they used more persuasive communication techniques, namely persuading, advising in instilling morality and religious values to their 
children. Certain times they sometimes use coercive communication in the form of threats to children. This is generally done if the child makes a mistake or negligence.

- Action against children who are negligent in performing prayer services

Based on the answers of the informants, it can be stated that the five speakers said that they still controlled the worship of their children's prayers. If you have entered the prayer time but he has not yet performed prayer, I remind him to immediately pray. At certain times when talking to children, I often tell about the law of praying, sin leaving prayer and the benefits of praying. If the child is still in school or outside the home because there is something needed, we still remind the child not to forget to pray through hand phone. Other speakers said that they still reminded children not to forget to pray before their children go to school or leave the house because there are certain needs.

\section{Conclusion}

Based on the results of the study, some conclusions can be drawn as follows:

1. The intensity of parent communication in sholeh children is relative, meaning that the intensity of parent communication with children depends on the situation and conditions that exist. If the situation and conditions allow for free time between parents and children, the intensity of communication will tend to be high, both in terms of quality and quantity.

2. The pattern of communication of parents in forming pious children is formed from aspects of time and atmosphere that exist when communication takes place. Generally communication takes place at night in an atmosphere of calm and comfort. Communication takes place face to face and the flow of communication takes place in two directions.

3. The method of cultivating skill values used by parents in forming pious children is more likely to be exemplary methods, then habituation methods, advice methods and disciplinary methods are the rules that must be obeyed by children and also consistency in enforcing rules and parental efforts to remind children remain in success.

4. Communication techniques used by parents in forming pious children are more likely to be initially persuasive, then if communication messages are less compliant then communication techniques become coercive.

\section{References}

Al-Quran dan Terjemahnya. Al-Muyassar, (Bandung: Sinar Baru Algensindo, 2012). Djamarah, Syaiful Bahri. Pola Komunikasi Keluarga (Sebuah Perspektif Pendidikan Islam), Jakarta: Rineka Cipta 2004.

Galvin, KM, Bylund, CL \& Brommel, BJ, Family Communication: Cohesion and Change, 6th ed. New York: Pearson Education, 2004.

Hendra, Yan, Disertasi, Pengaruh Komunikai Keluarga, Guru Pendidikan Agama Islam dan teman Sebaya Terhadap Etika Komunikasi Islam Siswa Sekolah Menengah Pertama di Kota Medan, Universitas Negeri Sumatera Utara, Medan: 2016. , Prosiding, Tafsir Tematik Komunikasi Verbal Dalam Al-Quran 
(Qaulan Balighan, an-Nisa: 63), Qaulan Layyinan, Thaha: 44). 2017 Islam, 2017.

Khon, Abdul Majid, Hadis Tarbawi (Hadis-Hadis Pendidikan), Jakarta: Kencana Prenada Media Group, 2014.

Kriyanto, Rachmat, Teknik Praktis Riset Komunikasi (Disertai Contoh Praktis Riset Media, Public Relations, Advertising,Komunikasi Organisasi, Komunikasi Pemasaran), Jakarta: Kencana Prenada Media Group, 2006.

Lea P, Stewart, Brent D. Ruben. Komunikasi dan Perilaku Manusia. terj. Ibnu Hamad, Jakarta: PT Raja Grafindo Persada. 2013.

Nawawi, Hadari, Pendidikan Dalam Islam. Surabaya: Al-Ikhlas, 1993.

Santrock, John W. Perkembangan Anak, ed. 11, terj. Mila Rachmawati and Ana Kuswanti, Jakarta: Erlangga, 2007.

Yusmiar, A. Pendidikan Anak dalam Rumah Tangga Berdasarkan Perspektif Islam, Bandung: Sarana Tutorial Nurani Sejahtera, 2015.

http://ejournal.unsrat.ac.id/index.php/actadiurna/article/view/4369 by JPM Tangkudung 2014. Downloaded on 21 October 2017

http://www.ejournalunisma.net/ojs/index.php/makna/article/viewFile/397/365 by A Sari 2011. Downloaded on 21 October 2017.

http://www.catatanmoeslimah.com/2006/04/sifatdanciri-cirianaksholeh membanggakan.html. Downloaded on 21 October 2017 